\title{
Rapid changes of the ice mass configuration in the dynamic Diablotins ice cave - Fribourg Prealps, Switzerland
}

\author{
S. Morard ${ }^{1}$, M. Bochud ${ }^{2,3}$, and R. Delaloye ${ }^{1}$ \\ ${ }^{1}$ Geography Unit, Department of Geosciences, University of Fribourg, Switzerland \\ ${ }^{2}$ Geology Unit, Department of Geosciences, University of Fribourg, Switzerland \\ ${ }^{3}$ Spéléo-Club des Préalpes Fribourgeoises (SCPF), Fribourg, Switzerland
}

Received: 1 June 2010 - Published in The Cryosphere Discuss.: 19 July 2010

Revised: 12 November 2010 - Accepted: 19 November 2010 - Published: 26 November 2010

\begin{abstract}
The Gouffre des Diablotins is a deep cave system located in the Swiss Prealps. In 1991, the lower entrance zone of the cave was almost free of ice. Nevertheless the ice volume sharply increased in 1994, plugging almost totally the gallery from the lower entrance. The ice cave has also experienced a flood period between 1996 and 2007 and very heterogeneous ice surface morphologies and textures have formed. Continuous cave climate measurements initiated in 2009 showed the predominant role of winter atmospheric air conditions to drive both the efficiency of chimney-effect air circulation and seasonal modifications of the ice mass. The main part of the ice loss is currently due to sublimation in wintertime.
\end{abstract}

\section{Introduction}

Several recent studies have focused on the processes involved in ice cave climate and mass balance (e.g. Luetscher, 2005; Luetscher et al., 2008), showing that fluctuations of ice mass depend directly on the hydrological and thermal regimes experienced by the cave during wintertime. Moreover processes involved in ice caves may be very complex, causing in particular cases a very heterogeneous distribution of ice and topoclimatic zones over short distances (Lauriol et al., 1988). Both in static and dynamic ice caves, ice mass is subject to strong seasonal modifications (Ohata et al., 1994a, b; Luetscher, 2004). As reported in numerous recent stud-

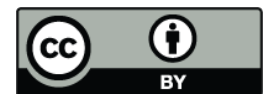

Correspondence to: S. Morard

(sebastien.morard@unifr.ch) ies, the ice volume has more or less continuously decreased during the last decades (Rachlewicz and Szczucinski 2004; Luetscher et al., 2005).

Several authors (Atkinson et al., 1983; Lauriol and Clark, 1993, Lismonde 1993; Ohata et al., 1994a; Luetscher, 2005; Lauriol et al., 2006) pointed out the major role played by air circulation in the ice cave climate and ice mass modifications. In mountainous areas, Lismonde (2002a) and Luetscher and Jeannin (2004a) assumed that the chimneyeffect driven by the thermal gradient between the inside and outside air temperature is at the origin of most air circulation observed in alpine karst systems due to the occurrence of several entrances located at different elevations. This ventilation system produces a negative thermal anomaly compared to the mean annual air temperature (MAAT) in the lower part of the system where cold air is aspirated in winter, and a positive thermal anomaly in the upper part of the system. The cooling effect of such seasonal reversible air circulation is also reported from porous debris accumulation like talus slopes at low elevation where the MAAT is largely positive (Delaloye et al., 2003, Morard et al., 2008). This process is also currently used in embankments to preserve permafrost conditions under transportation infrastructures at high latitude or high altitude (e.g. Arenson and Sego 2006).

This paper will present the particular case of a dynamic ice cave located in the Fribourg Prealps (Switzerland), in which the volume of ice has sharply increased in the middle of the 1990's. The goal of this paper is to try to determine which processes are currently involved in the ice cave climate and seasonal modifications of the ice mass, in order to explain this apparently surprising behaviour.

Published by Copernicus Publications on behalf of the European Geosciences Union. 


\section{Site description}

The Gouffre des Diablotins is located in the Morteys Valley extending northeast of the highest summit of the Fribourg Prealps (Switzerland), the Vanil Noir $(2389 \mathrm{~m}$ a.s.l., $46^{\circ} 32^{\prime} 09^{\prime \prime} \mathrm{N}, 07^{\circ} 09^{\prime} 43^{\prime \prime}$ E, Fig. 1a). Geologically, the valley corresponds to a synclinal valley formed in massive limestone from the Préalpes Médianes. The area is also an old glacial valley with high cliffs on both south-eastern and north-western slopes. More than 50 cave entrances are inventoried in the valley, and the longest cave is the Réseau des Morteys which is $8900 \mathrm{~m}$ long and $550 \mathrm{~m}$ deep (SCPF 2010). The MAAT recorded at the nearby meteorological station in Moléson summit ( $1974 \mathrm{~m}$ a.s.l.) is about $+2.8^{\circ} \mathrm{C}$, and winters are characterized by average air temperatures of $-2.2^{\circ} \mathrm{C}+/-1.1{ }^{\circ} \mathrm{C}(1983$ and 2009$)$ and snowy conditions (about 3-4 m of snow).

The Gouffre des Diablotins is the deepest cave of the area with a depth of $652 \mathrm{~m}$ (Fig. 1c), and it is developed in the vertical massive limestone of the south-eastern slope of the Vanil-Noir syncline (Fig. 1a). The cave has two entrances, the lower one at $2007 \mathrm{~m}$ a.s.1., $30 \mathrm{~m}$ high in a north oriented rockwall, and the upper one at 2092 m.a.s.l., on the top of the Rochers des Tours (Fig. 1b). Both entrances are linked together by a $105 \mathrm{~m}$ vertical shaft and a $50 \mathrm{~m}$ descending gallery (called the "lower gallery" in this paper). The deepest part of the cave can be reached from a gallery starting at the intersection between both entrances ("gallery junction" on Fig. 2a). The Diablotins ice cave is also the most important ice volume known in the Fribourg Prealps (estimated to about $100 \mathrm{~m}^{3}$ ). Today the ice extends discontinuously along the lower gallery. The two lower thirds of the $105 \mathrm{~m}$ vertical pit are also permanently covered by ice (Fig. 2a) (Bovey, 1995). Due to its L-shaped configuration with two entrances located at different elevations, the cave could be attributed to the dynamic type, with the occurrence of a ventilation system by chimney-effect. Moreover the importance of deep air circulation process is also pointed out by the name Diablotins ("little evil creatures") which refers to the presence of permanent strange murmurs inside the cave system (Bovey, 1995).

\subsection{Archives of speleological investigations}

The particularity of this ice cave is due to the rapid changes of the ice mass configuration observed during the last two decades and recorded in the archives of the Spéléo-Club des Préalpes fribourgeoises (SCPF) (Jutzet, 1991; Bovey, 1995). The main components of the Diablotins ice cave are presented in detail in Fig. 2.

In August 1983 the lower gallery was completely plugged by ice. However in summers 1991 and 1992, the ice disappeared almost completely from the lower gallery (Fig. 2c), allowing intense explorations of the karstic network during these years. In August 1992 the speleologists reached -652 $m$ in the Gouffre des Diablotins (Fig. 1c). In July 1993 ice plugged the bottom of the "ice slide" and a fixed rope was installed in the "chimney-room" to access the "gallery junction" through the top of the room. Since 1994 the ice mass has sharply increased to finally plug completely the lower gallery in 1995 near the "gallery junction". Since then it has been impossible to reach the intersection with the vertical shaft again from the lower entrance. In 1996 ice was found in the "chimney-room". Between 1997 and 2001, a large quantity of water mixed with ice was observed in the lower gallery at the current "ice plug" location and impeded the access to the "chimney-room". A pipe was installed in order to evacuate this unfrozen water, but the lower gallery was still flooded in 2005. Since 2007 cold airflow was again perceptible along the ice mass.

\subsection{The Diablotins ice cave in 2009-2010}

In order to better understand the processes occurring in the Diablotins ice cave, the lower gallery was visited more frequently in June, October, November 2009, March and May 2010 to observe the current state of the ice cave (cave climate, configuration of the ice mass, types of ice) and its evolution at a seasonal time scale. A fixed string was installed above the "ice plug" to measure the changes of elevation of the ice surface. Some measurements were also taken with a high precision portable weather station (Skywatch GEOS 11, JDC Electronics), in particular the airflow direction and velocity pattern was measured at various places inside the lower gallery on different dates (Fig. 2b).

The spatial distribution of ice along the lower gallery is very heterogeneous, but the ice content is generally more important on the south-west side of the gallery than on the north-east side. Moreover the ice mass configuration in the Diablotins ice cave, as the morphology of ice surface, have experienced important seasonal modifications in 2009-2010. The state of the ice cave in 2009 is presented in Figs. 2a, 3 and 4.

\subsubsection{Seasonal modifications of the ice mass}

14 June 2009: A snow accumulation partially occupied the room at the lower entrance (Fig. 2a). Ice plugged the lower gallery at the "ice plug" location, but a strong and cold outward airflow $\left(-0.3^{\circ} \mathrm{C}, 2.5-3 \mathrm{~m} / \mathrm{s}\right)$ was perceptible through a small opening on the top of the ice mass. The cave walls were also covered by hoarfrost (Fig. 4e).

31 October 2009: An ice stalactite had formed before the "ice plug", indicating the outlet of percolating unfrozen water. At the "ice plug" location, outward airflow was still present, but the cave walls were at that time only covered by few hoarfrost crystals. The elevation of ice surface had diminished by about $4 \mathrm{~cm}$ where the fixed string was installed (Table 1), and more at its extremity. Thus it was again possible to enter the ice cave beyond about $20 \mathrm{~m}$ to 

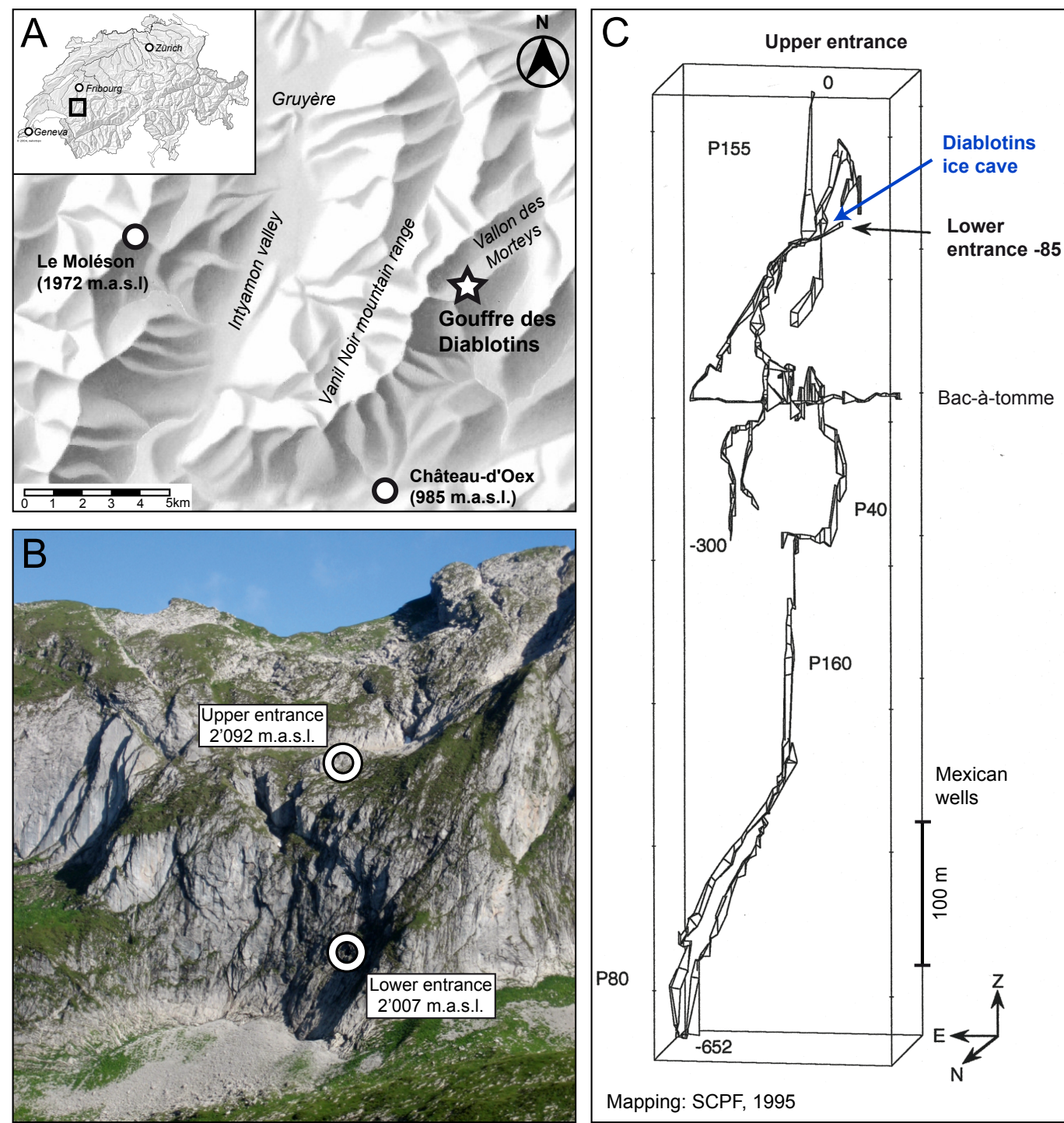

Mapping: SCPF, 1995

Fig. 1. (A) Location of the Gouffre des Diablotins and the two meteorological stations of Moléson summit and Château-d'Oex; (B) Location of the upper and lower entrances; (C) Map of the Gouffre des Diablotins karstic system.

Table 1. Changes in the distance between the rock ceiling and the ice surface at the ice plug location, and airflow direction and velocity measured with portable anemometer (GEOS 11). IP: ice plug; TCR: top of the chimney-room; IS: ice slide (chimney-room).

\begin{tabular}{|c|c|c|c|c|c|c|}
\hline \multirow[b]{2}{*}{ Date } & \multicolumn{3}{|c|}{ Changes of elevation $(\mathrm{cm})$ of the ice surface at the ice plug } & \multicolumn{3}{|c|}{ Airflow pattern } \\
\hline & Distance $(\mathrm{cm})$ & From 14.06.09 & From previous date & Location & Direction & Velocity $(\mathrm{m} / \mathrm{s})$ \\
\hline 14 June 2009 & 114 & - & - & IP & Outflow & $2.5-3.0$ \\
\hline 31 October 2009 & 118 & -4 & -4 & IP & Outflow & 1.5 \\
\hline 21 November 2009 & 120 & -6 & -2 & TCR & Outflow & not measured \\
\hline 9 March 2010 & 124 & -10 & -4 & IS & Inflow & $0.8-1.9$ \\
\hline 22 May 2010 & 118 & -4 & +6 & IS & Outflow & not measured \\
\hline
\end{tabular}



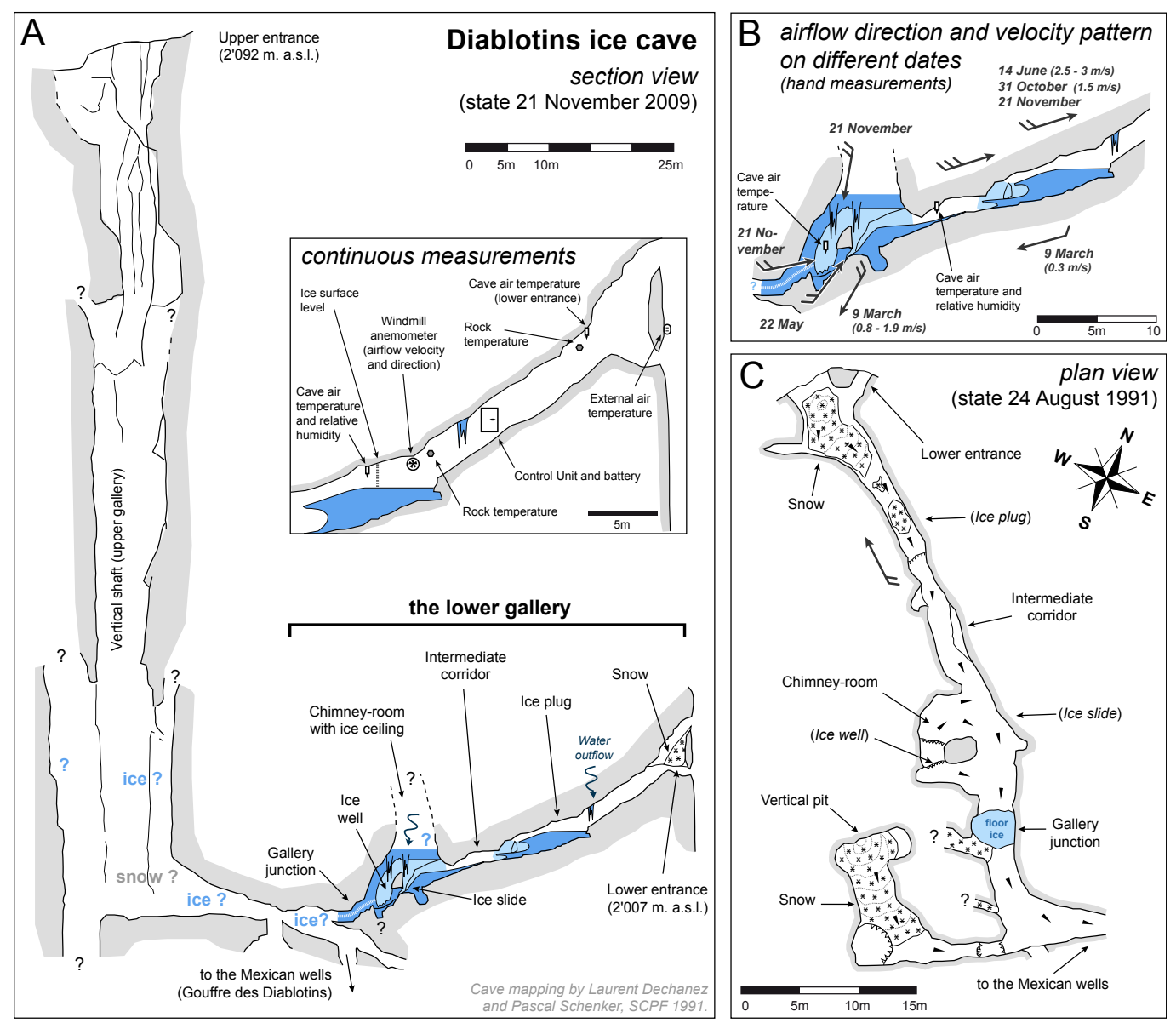

Fig. 2. (A) Section view of the entrances zone of the Gouffre des Diablotins with ice mass configuration encountered in 21 November 2009 and the location of the devices used for continuous measurements; (B) Pattern of airflow direction and velocity observed in 2009-2010 and measured with a portable anemometer on different dates (wind barbs: one feather denotes an average velocity of $<1 \mathrm{~m} / \mathrm{s}$, two feathers $1-3 \mathrm{~m} / \mathrm{s}$, three feathers $>3 \mathrm{~m} / \mathrm{s}$ ); (C) Plan view of the entrances zone of the Gouffre des Diablotins; the gallery was almost free of ice on 24 August 1991 (cave mapping by Laurent Dechanez and Pascal Schenker, SCPF). Rock is drawn in grey, ice mass in dark blue or in light blue when it occupied only the south-west part of the lower gallery.

the "chimney-room" where a particular flat ice ceiling - not observed in 1996 - had formed. The rope installed in 1993 crossed the ice ceiling and its extremity was caught in the ice (Fig. 3c). Cave walls at the end of the "chimney-room" were also covered by a thin layer of ice.

21 November 2009: An outward airflow always occurred inside the lower gallery and the surface of the "ice plug" diminished again by about $2 \mathrm{~cm}$ since 31 October (Table 1 ). In the "chimney-room", water was seeping along the ice stalactites and the cave walls, and airflow was coming out from the ice ceiling. The gallery was plugged by ice in the "ice well", and the "gallery junction" was not reached (Fig. 3d). Nevertheless, the bottom of the ice mass was pierced by a decimetre conduct where an outward airflow was perceptible (Fig. 4o), maybe connected farther to the vertical shaft.

9 March 2010: The lower entrance was partially blocked by snow. A weak inward airflow was perceptible and the surface of the "ice plug" was $10 \mathrm{~cm}$ lower than in June (Table 1).
In many places along the lower gallery, the ice volume had obviously diminished since November 2009. The ice surface was dirty and covered by a thin layer of dust, originating from the rock ceiling of the gallery. In the "chimney-room", the cave walls were dryer than in November and no percolating water was perceptible. The airflow rushed in the "ice slide" trough small holes newly formed in the ice (Table 1).

22 May 2010: New clear transparent ice had formed on the floor of the ice cave from the "ice plug" $(6 \mathrm{~cm}$ higher than in March) until the "chimney-room" (Table 1 and Fig. 4h). The cave walls of the lower gallery were covered by hoarfrost, but no strong airflow was perceptible at the "ice plug". In contrast in the "chimney-room", an outward airflow came from holes in the bottom of the "ice slide". Thus a sharp ice mass increase is recorded during the snowmelt period as normally reported for ice caves (Rachlewicz and Szczucinski, 2004; Luetscher, 2005). 

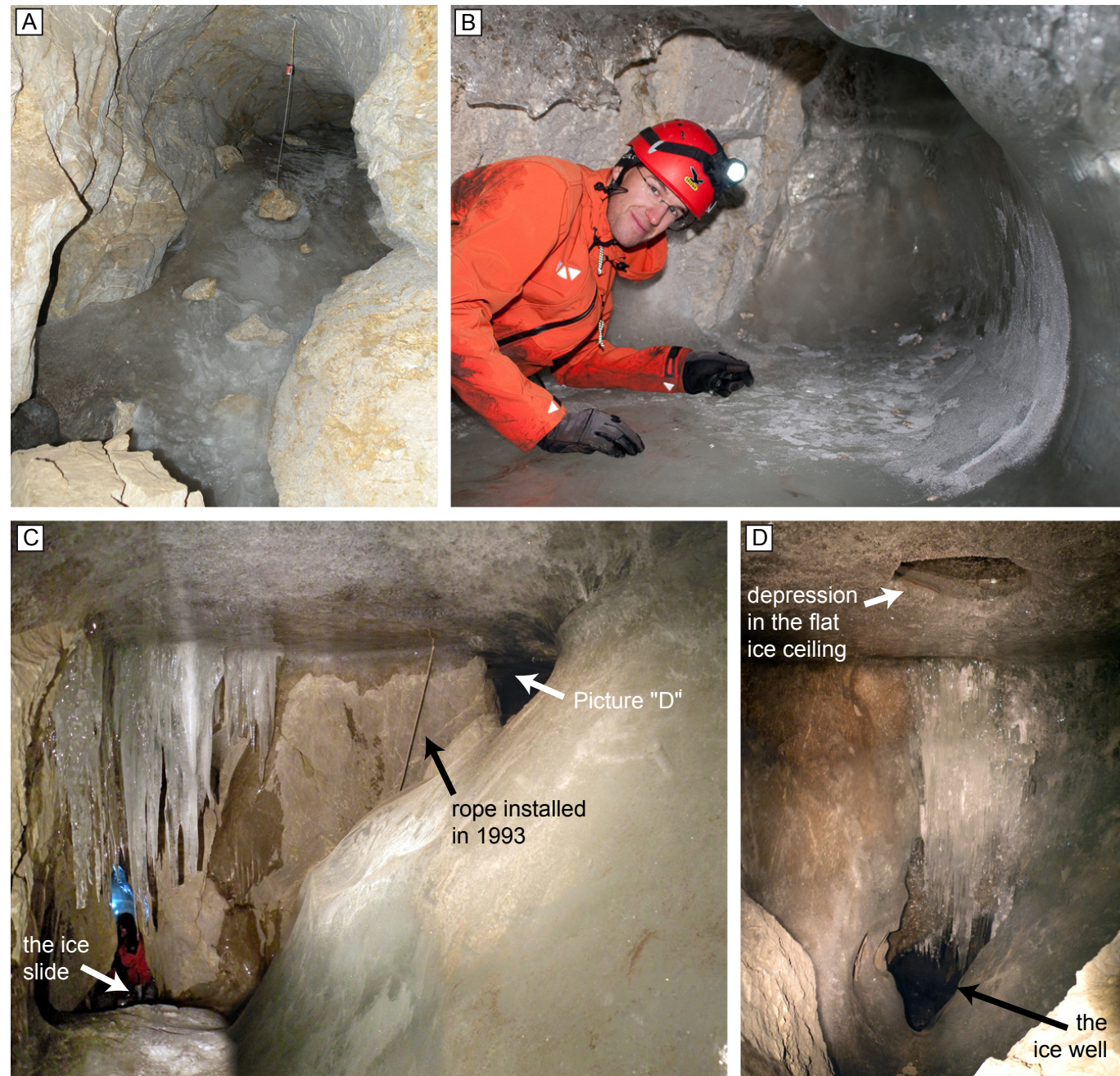

Fig. 3. Pictures of the main parts of the ice cave. (A) "Ice plug" (31 October 2009); (B) U-shaped hollow under the "ice plug" (31 October 200); (C) "Chimney-room" with the flat ice ceiling (9 March 2010); (D) "Ice well" at the end of the chimney-room (9 March 2010).

\subsubsection{Types of ice and morphology of ice surface}

Observations of the type of ice as well as the morphology of the ice surface could be used to assess both the origin of ice (Ford and Williams, 1989, Luetscher and Jeannin 2004b) and the processes involved in its accumulation and ablation (Bella, 2006).

Ice observed in the Diablotins ice cave is mainly opaque to clear, sometimes with rock debris incorporated in the ice mass (Figs. 3a and 4f). Under the "ice plug", coarse polycrystalline ice surface structures were observed in early winter (Fig. 4k), but have disappeared in March (Fig. 4i). At some places ice is extremely transparent and smooth and contains sometimes some bubbles (under the "ice plug" and in "intermediate corridor") or undefined internal structures (ice ceiling, Fig. 4i, j, n). Floor ice covered the "intermediate corridor" (Fig. 41). Finally, seasonal forms of ice accumulation developed as ice stalactites, fine layers of ice in the cave walls, ice flowstone (Fig. 4f, h) and hoarfrost (Fig. 4e). Hoarfrost is preferentially found in the largest sections of the lower gallery where a decompression of the airflow occurred. According to the classification of Ford and Williams (1989), the origin of the ice mass observed in the Diablotins ice cave can be attributed to congelation processes, mainly to freezing of infiltrating water and also partially to freezing of ponded, static water.

According to Bella (2006), several ice ablation forms observed in the ice cave are attributed to air circulation. This comprises mound-shape depressions carved in the "ice plug" on the leeward side of a stone caught in the ice mass (Fig. 3a), huge U-shaped hollows (Fig. 3b), scallops and oval moundshaped elevations (Fig. 4g), and quasi-spherical depressions in the flat ice ceiling (Fig. 4m). Ablation channels developing in the ice mass at the bottom of the "ice well" can originate from the runoff of unfrozen water (Fig. 4o). 

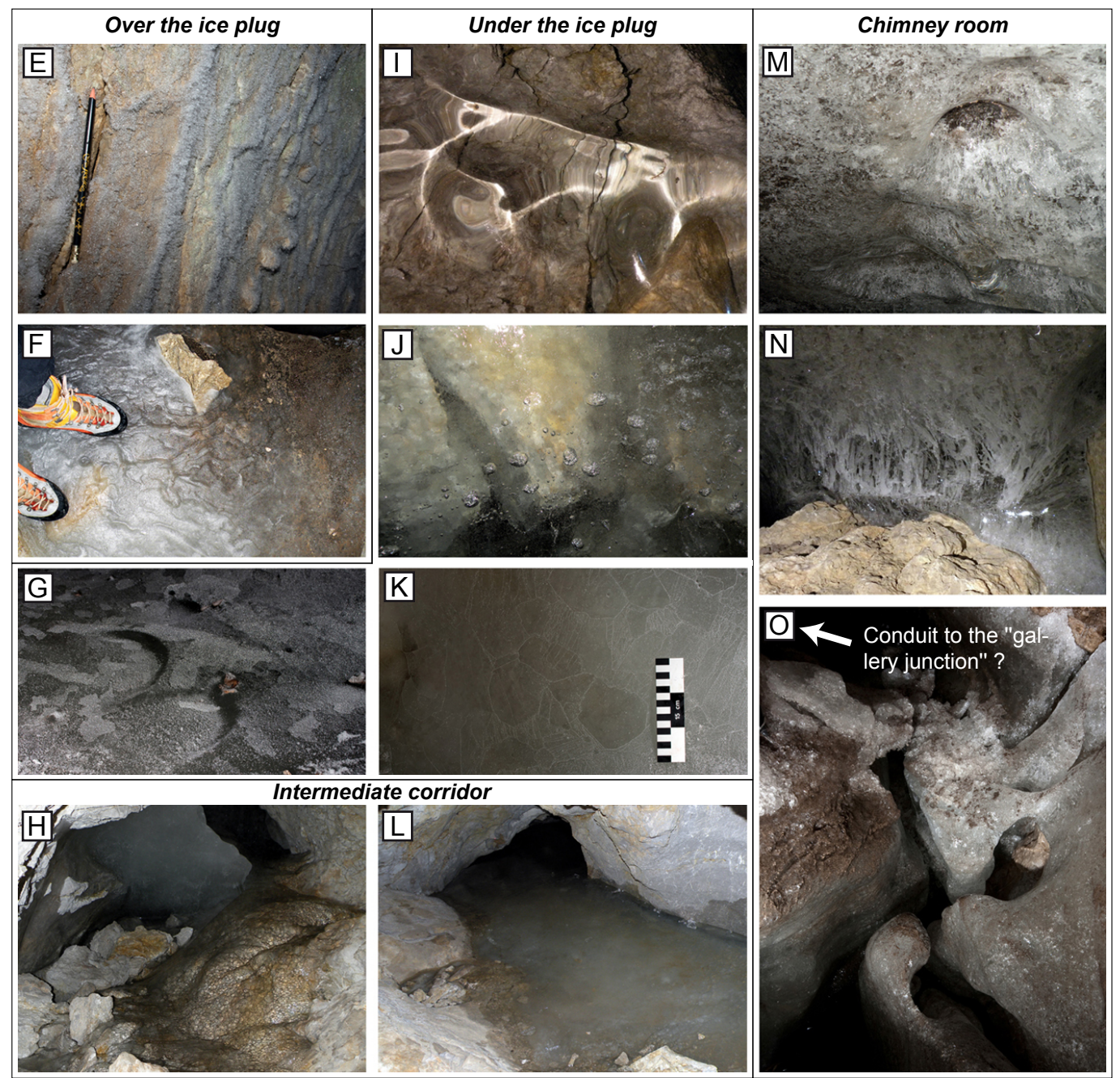

Fig. 4. Different types of ice morphology. (E) Hoarfrost on the wall at the "ice plug" (16 June 2009); (F) Ice flowstone over the "ice plug" (31 October 2009); (G) Oval mound-shaped elevations in the "intermediate corridor" (21 November 2009); (H) Ice flowstone before the "intermediate corridor" (22 May 2010); (I) Transparent ice under the "ice plug" (9 March 2010); (J) Bubbles in clear ice (31 October 2009); (K) Large polycrystalline structures at the ice surface under the "ice plug" (21 November 2009); (L) Floor ice in the "intermediate corridor" (22 May 2010); (M) Quasi-spherical depressions in the flat ice ceiling (22 May 2010); (N) Transparent ice with internal structure inside the flat ice-ceiling (9 March 2010); (O) Ablation channel and conduct build by waterflow in the ice mass at the end of the "ice well" (21 November 2009).

\section{Continuous measurements of the Diablotins ice cave climate}

\subsection{Devices}

An autonomous temperature data logger (UTL-1, Geotest AG, accuracy: $+/-0.25^{\circ} \mathrm{C}$ ) has recorded the cave air temperature at the "ice plug" since 16 June 2009. Moreover, the lower gallery was equipped on 31 October 2009 with several devices connected to a meteorological station (MADD Technologies) to measure the cave air temperature and relative humidity, the airflow velocity and direction, the rock temperature at $5 \mathrm{~cm}$ depth and the external air temperature.
Accuracy is $+/-0.1{ }^{\circ} \mathrm{C}$ for the temperature sensors and $+/-$ $1 \%$ for the relative humidity. The windmill anemometer is located at the "ice plug" and had an accuracy of $+/-0.1 \mathrm{~m} / \mathrm{s}$ and a sensitivity of about $+/-0.2 \mathrm{~m} / \mathrm{s}$. The data were recorded in hourly intervals. Unfortunately, between 21 November 2009 and 22 May 2010, the station recorded only every 10 hours due to a calendar problem. Two additional autonomous temperature and relative humidity loggers (iButton, resolution: $0.5^{\circ} \mathrm{C}$ and $1 \%$, time interval: $3 \mathrm{~h}$ ) were placed in the "intermediate corridor" and in the "ice well" at the end of the "chimney-room" on 21 November 2009. The locations of the devices are shown in Fig. 2a, b. 


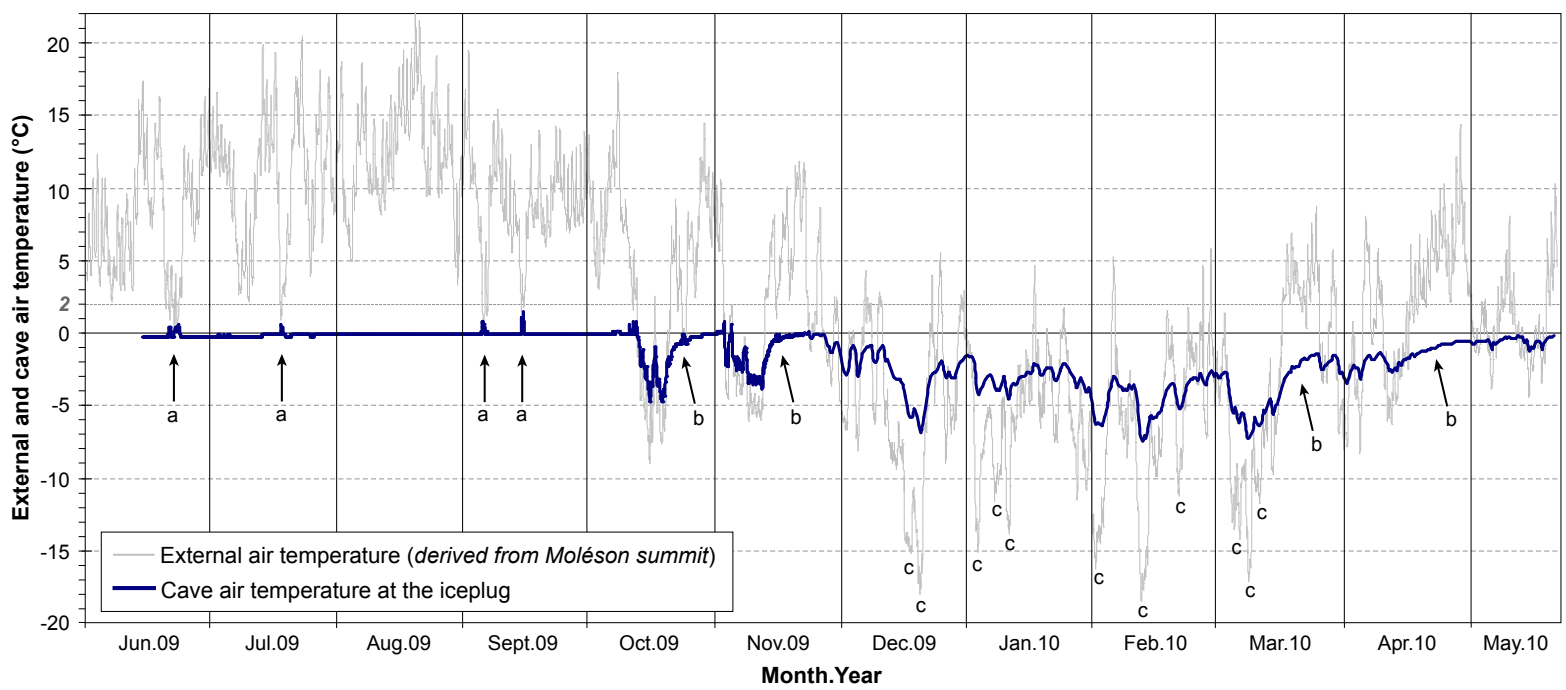

Fig. 5. Evolution from June 2009 to May 2010 of external air temperature and cave air at the "ice plug". (a) Changes of airflow direction in summertime; (b) Thermal rebalancing of the cave air temperature after strong inward ventilation phases in early and late winter. (c) Periods of cold weather in wintertime.

In addition to these direct observations and measurements, data from two close meteorological stations of the Meteoswiss network are used to determine the external atmospheric conditions (Fig. 1a). Air temperature and relative humidity are provided by the Moléson summit station (1974 m a.s.l.). A very good linear correlation $\left(r^{2}=0.942\right)$ was found between the external air temperatures measured directly outside the lower entrance of the cave and those from the Moléson summit $\left(0.6^{\circ} \mathrm{C}\right.$ warmer $)$. Thus, due to the calendar problem of our meteorological station, data of external air temperatures presented in this paper were derived from the hourly data of the Moléson summit. As snow records were not available from Moléson summit, data from Château d'Oex (985 ma.s.l) were used to estimate the inter-annual variability of snowfall.

\subsection{Seasonal evolution of the cave climate}

\subsubsection{Stable and continuous regime of outward airflow during summer}

During summertime the cave air temperatures are stable at -0.3 to $0^{\circ} \mathrm{C}$ (Fig. 5) and are most of time independent from the external air temperatures, except during short periods of colder weather (external air temperatures between $0^{\circ} \mathrm{C}$ and $+2{ }^{\circ} \mathrm{C}$ ). The warmest cave air temperatures are recorded during such events (arrows "a" on Fig. 5). During this constant period of outward airflow, the air is also saturated $(\mathrm{rH}=$ $100 \%$ ) at the "ice plug" (Fig. 6b). Rachlewicz and Szczucinski (2004) attributed such a stable thermal state to the latent heat consumption for melting.

\subsubsection{Periods of reversing airflow}

In autumn, airflow direction reverses in the lower gallery when the external air temperature crosses a thermal threshold of about $+2{ }^{\circ} \mathrm{C}$ (Fig. 5). Below that limit, an inward airflow is recorded inside the lower gallery as shown by the synchronous behaviour between the cave air and the external air temperatures (Lismonde, 2001; Luetscher, 2005; Figs. 5 and $6 \mathrm{c})$. The thermal threshold is also associated to the changes in relative humidity from saturated (outflow) to unsaturated state (inflow) (Fig. 6b) and by the rapid reverse of the airflow direction (Fig. 6d), agreeing well with theory (Lismonde, 1993). Moreover on both sides of this limit of $+2{ }^{\circ} \mathrm{C}$, the airflow velocity increased due to higher temperature gradient between the inside and the outside of the cave. Velocities of about $1 \mathrm{~m} / \mathrm{s}$ are recorded in autumn but remained zero in most part of winter. These values were lower than those recorded with a portable anemometer (Fig. 2b and Table 1). As the fluctuations of the cave air temperature indicated a ventilation effect, the windmill anemometer has probably not worked properly during winter or the airflow velocity was under its level of sensitivity.

An interesting behaviour can also be noticed for the cave air temperature. At the beginning of an inward ventilation phase, the cave air temperature followed immediately the variations of the external air temperature. On the other hand, at the end of such an event - like in autumn and at the end of winter - the air temperature inside the cave reacted more slowly and needed a few days to reach again $0{ }^{\circ} \mathrm{C}$ (arrows "b" in Fig. 5). Rock temperatures also experienced such a varying behaviour (Fig. 6e). 

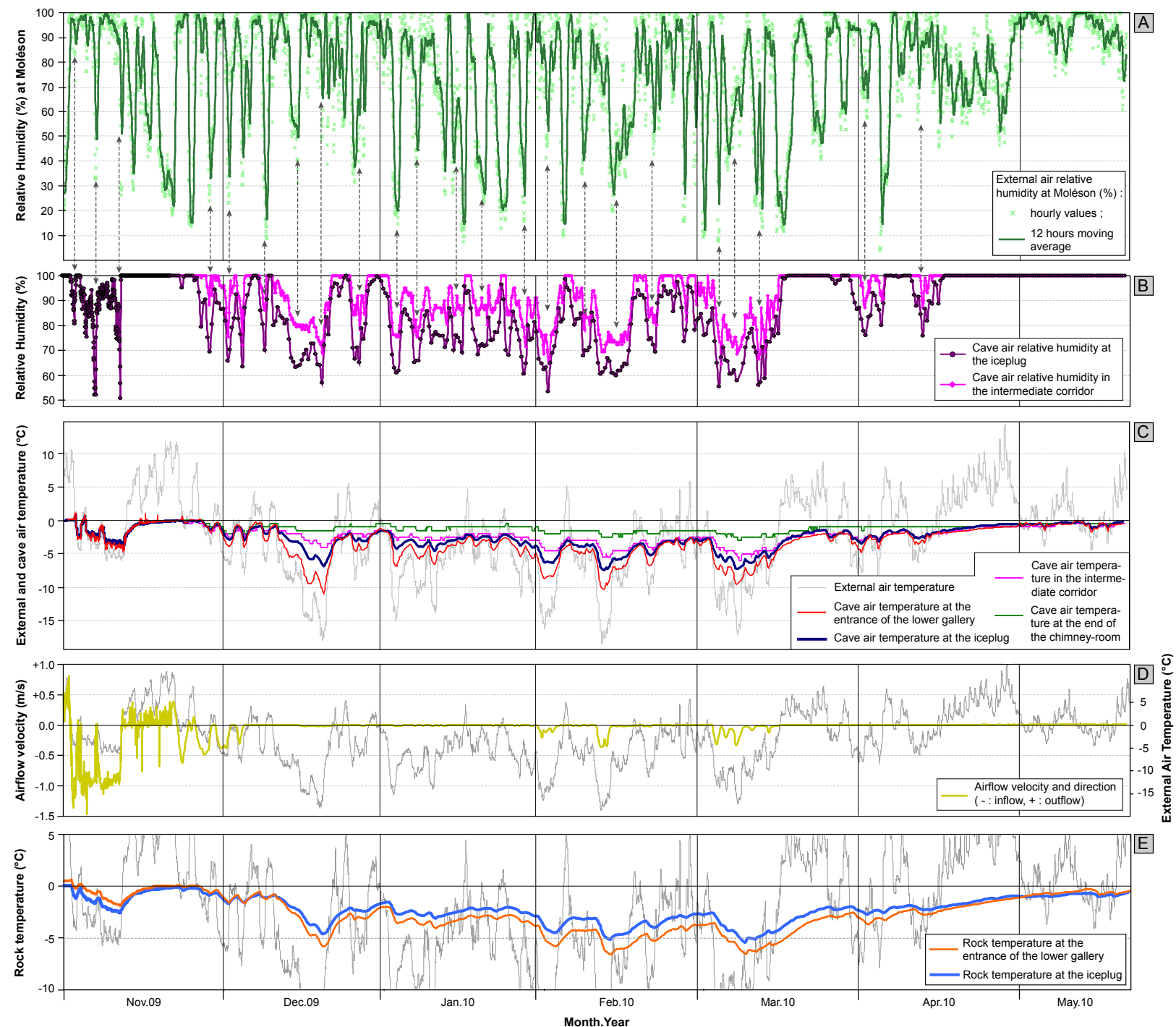

Fig. 6. Cave climate of the lower gallery from November 2009 to May 2010. (A) External air relative humidity measured at Moléson station; (B) Cave air relative humidity at the "ice plug" and in the "intermediate corridor"; (C) External and cave air temperatures at the "entrance" of the lower gallery, at the "ice plug", in the "intermediate corridor" and in the "ice well" at the end of the "chimney-room"; (D) Airflow velocity and direction at the "ice plug"; (E) Rock temperatures at the "entrance" of the lower gallery and at the "ice plug". The gray curve corresponds to the external air temperature derived from the hourly values of the Moléson summit.

Table 2. Average and standard deviations of cave air temperature and relative humidity in the Diablotins ice cave, when the external air temperature is lower than $+2^{\circ} \mathrm{C}$ (inflow phases).

\begin{tabular}{lcccccc}
\hline & & External air & Lower entrance & Ice plug & Intermediate corridor & Chimney-room \\
\hline \multirow{2}{*}{ Cave air temperature $\left({ }^{\circ} \mathrm{C}\right)$} & Mean & -4.7 & -3.3 & -2.7 & -2.5 & -1.3 \\
& Stdev & 4.4 & 2.1 & 1.5 & 1.2 & 0.6 \\
\hline \multirow{2}{*}{ Cave air relative humidity $(\%)$} & Mean & 79.3 & - & 84.9 & 91.0 & - \\
& Stdev & 22.6 & - & 12.4 & 9.5 & - \\
\hline
\end{tabular}




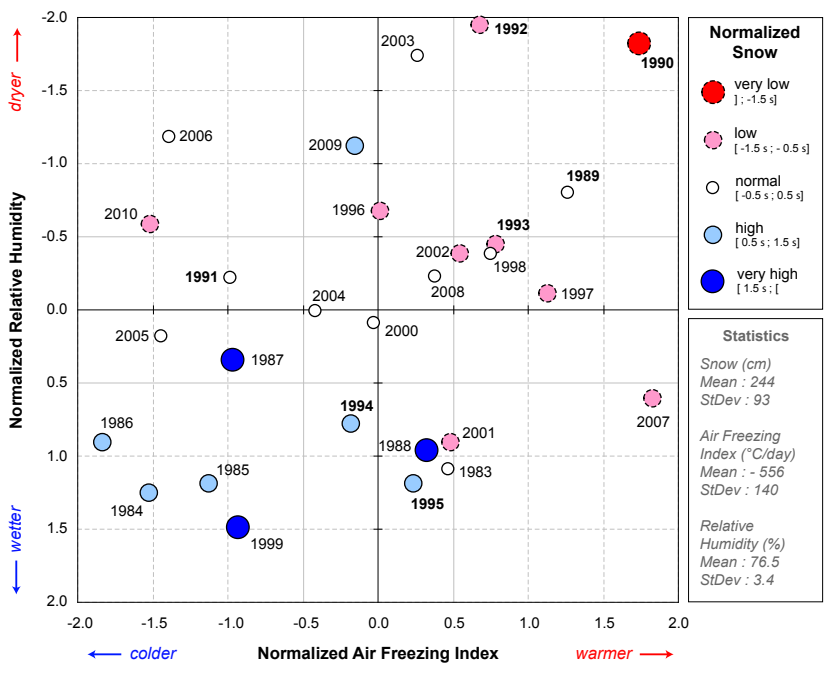

Fig. 7. Reconstruction of winter meteorological conditions (air temperature and relative humidity, snow) from 1983 (Oct 1982-Apr 1983 ) to 2010. Normalized values are based on the average and standard deviation from the period 1983-2009.

\subsubsection{Cooling and drying of the ice cave in wintertime}

During phases of inward airflow in winter, the cave air temperature warmed from the "lower entrance" to the end of the "chimney-room", with increasing differences during periods of cold weather (Fig. 6c). Nevertheless, even if attenuation in the fluctuations of cave air temperatures from the "lower entrance" to the "chimney-room" is observed (Table 2), all parts of the lower gallery are affected by the winter cooling.

A significant part of the heat advected by the airflow inside the ice cave is also transmitted and stored by thermal conduction in the cave walls. The cooling of the rock during winter was also more important close to the "lower entrance", where the cave air temperature is colder than at the "ice plug" location (Fig. 5e).

While warming an air mass should theoretically cause a reduction in its relative humidity (Forbes, 1998), the reverse phenomenon is registered in the Diablotins ice cave during the inward ventilation phases (Fig. $6 \mathrm{~b}$ and Table 2). In general, the course of air temperature and relative humidity closely follow each other. Moreover the cave air humidifies itself when it penetrates deeper inside the lower gallery and shows a similar behaviour as the external air relative humidity. This means that, during inward ventilation phases, variations of relative humidity inside the lower gallery are mainly driven by the evolution of relative humidity of the atmospheric air ("double-arrows" in Fig. 6a, b). In contrast when the external air temperature reached again the thermal threshold for the change of airflow direction, during periods of mild weather in wintertime, the cave air relative humidity increased rapidly to $100 \%$ and did not follow the evolution of the external air relative humidity.

\section{Discussion}

\subsection{Heat exchange between cave air, rock and ice}

The cooling of the rock temperature in winter as the thermal gradient of the cave air measured between the "lower entrance" and the "chimney-room" can be attributed to the heat exchange between the cave air with the rock walls and the ice mass (Lismonde, 2002b). According to Luetscher (2005), much more energy is stored within the ice (latent heat) than in the rock (sensible heat). These heat fluxes could also explain the thermal damping in the fluctuations of cave air temperatures at the end of an inward ventilation phase and the inertia of the system due to the thermal state of rock and ice (Lismonde 2002b).

In consequence an important cold reservoir can form during winter in the lower gallery of the Diablotins ice cave. According to Saar (1955) winters with long periods of low temperatures weather are more favourable situations for the presence of dynamic ice cave with chimney-effect ventilation system. In addition to this exogenic factor, the cooling effect could also be increased by endogenic ones (Luetscher, 2005), particularly by the absorption of latent heat due to evaporation/sublimation processes. On the other hand, the condensation warming effect due to ice formation during snowmelt periods or hoarfrost formation during phases of saturated outward airflow seems to be weak, as shown by the gradual and slow warming of the cave in April - May.

\subsection{Part of sublimation and melting in the ice mass loss}

A significant loss of ice mass had been observed in wintertime, despite the fact that the cave air temperature always remains below the freezing point. The entire lower gallery is thus subject to sublimation processes, as evidenced in March by the disappearance of ice layers on the cave walls in the "chimney-room", the polishing of the ice stalactites and the ice walls in the "intermediate corridor" (Fig. 4h) or by the presence of a fine dust layer on the floor. Law and vanDijk (1994) interpreted the existence of this thin layer of sediments as a result of the sublimation of the frozen surface of the cave walls. The apparently counter-intuitive relationship between cave air temperature and relative humidity in the different parts of the ice cave could also be interpreted as an evidence of very efficient sublimation events in winter. By warming, air becomes dryer and theoretically increases the rate of sublimation. But simultaneously rock and ice will transfer their moisture to the cave air (Lauriol et al., 1988; Lismonde 2002b), which explains the increase of relative humidity between the "ice plug" and the "intermediate corridor" despite increasing cave air temperature. The drying of the cave following the advection of external air in winter is more intense near the entrance (Forbes, 1998), but its effect can exceed a kilometre as reported by Lismonde (2002a) for the Trou qui Souffle (Isère, France). Ohata et al. (1994) 
considered the aspiration of dry and cold air as the main element of heat balance in ice cave. By seasonal measurements of the ice mass balance, Rachlewicz and Szczucinski (2004) also considered that the sublimation process caused the most intensive rate of ice mass loss, even if in their case the ice was primarily lost by melting.

The ice mass will also decrease in summer due to melting caused by warm percolating water, after thunderstorms for instance (Luetscher, 2005) and by the penetration of warmer air from the upper entrance. A part of the ice melting could also be caused by heat supply from the cave walls, the northeast side of the "ice plug" being indeed about $10 \mathrm{~cm}$ away from the lateral wall. In the Diablotins ice cave, only a loss of $4 \mathrm{~cm}$ of ice was measured between June and October 2009 on the elevation of the "ice plug". Moreover, the measurements were made after a 10 day period of inward airflow in midOctober, when sublimation probably occurred. Thus summer melting seems to be less important compared to winter sublimation in the Diablotins ice cave.

\subsection{Relative importance of variables controlling the sublimation rate}

In the Diablotins ice cave, sublimation could be considered as the main process controlling the rate of ice loss. But which variables could best explain this process observed in wintertime? Law and vanDijk (1994) made a review of sublimation as a geomorphic process on frozen sediments, ice and snow, and discussed the relative importance of changes in relative humidity, air temperature and wind velocity.

Some experiments showed that a decrease in relative humidity from $90 \%$ to $80 \%$ had doubled the rate of sublimation (Law and vanDijk 1994). Moreover sublimation seems to be more efficient between -1 and $-4{ }^{\circ} \mathrm{C}$. Below $-4^{\circ} \mathrm{C}$, the rate will decrease to become very low at $-12{ }^{\circ} \mathrm{C}$. A more intense airflow velocity (depending on the thermal gradient between the external air and cave air temperatures) will also increase the rate of sublimation, by raising the rate of heat exchange of water molecules between the rock and ice surface, and the air. Nevertheless the magnitude of these effects is widely discussed (Law and vanDijk, 1994). Anyway all experiments showed that the rate of sublimation increase by (1) decreasing relative humidity of air, (2) rise in air temperature until the freezing point and (3) increasing wind velocity.

Thus dry air conditions in winter and strong temperature contrasts (by increasing the airflow velocity) could favour the sublimation rate and could be seen as unfavourable conditions for the ice mass balance. Nevertheless, in the current state of knowledge, it is not possible to determine more precisely the relative importance of these three factors in the sublimation rate observed in the Diablotins ice cave during the winter.

\subsection{Possible causes of decadal evolution of the Diablotins ice mass}

Based on the analysis of one year of measurements in the Diablotins ice cave - which showed that the climate of the ice cave is mainly influenced by winter conditions and that air circulation plays a major role in its behaviour - we have tried to determine which meteorological parameters have changed for the last 20 years. A reconstruction of the atmospheric winter conditions (relative humidity of air, daily sum of negative air temperature (air freezing index) and quantity of snow) was carried out since 1983 (Fig. 7). Daily meteorological data were taken from the two closest stations of the Meteoswiss network (Fig. 1a).

This analysis has to be considered mainly as a qualitative approach to understand the potential causes of the observed development of ice in the Diablotins cave since 1983. It is based on three main hypotheses: (1) the level of relative air humidity would play an important role for the rate of ice sublimation when external air is aspirated in the lower gallery, (2) during periods of low temperatures, a strong cold reservoir could form inside the cave, favouring the freezing of percolation water and the preservation of ice in summertime, (3) snowy winters would provide more percolation water for the formation of congelation ice during the period of snowmelt. The results of the reconstruction showed that the winters 1989, 1990, 1992 and 1993 were mild, less snowcovered and with dry air conditions (Fig. 7). These years correspond with the low ice content period of the ice cave. Contrasting meteorological conditions were encountered during the winters 1994 and 1995, when the strong increase of the ice mass was observed.

Jutzet (1991) and Bovey (1995) also proposed the hypothesis of compression/decompression of the airflow as an explanation for facilitating the freezing of percolation water in some parts of the lower gallery. Indeed airflow velocity will depend both on the thermal gradient between the inside and the outside of the cave, but also on the diameter of the gallery. The airflow will accelerate in the narrow sections of the gallery and will thus be compressed. At the exit of narrow sections, the pressure of the airflow will theoretically decrease and favour the freezing of percolating water and/or the vapour of the air (hoarfrost). Such a process, in addition with the changes of the meteorological variables, could possibly explain the pronounced local variability of ice mass changes observed in the Diablotins ice cave.

It is more difficult to explain the evolution of the ice mass between 1997 and 2005, when the lower gallery was almost entirely flooded and no strong airflow was perceptible by the speleologists. It is possible that during the following cold, wet and snowy winters 1994 and 1995, ice almost totally filled the cracks and the narrow sections at the "gallery junction" and at the "ice slide". That could have prevented water from draining and creating a water-pocket at least during a certain time in summer during the following years. The air 
circulation could have been stopped or reduced during such event. Nevertheless, observations of the airflow in 20092010 have illustrated the complex pattern in its direction and origin in the "chimney-room" (Fig. 2b). Since 2007 the water pocket has totally disappeared and the return of a strong airflow explains the current morphology of the ice surface (Figs. 3 and 4) determined by air circulation and ice sublimation (Bella, 2006).

\subsection{Origin of the flat ice ceiling in the chimney-room}

One of the most spectacular feature in the Diablotins ice cave is found in the "chimney-room", where an important ice mass and a particular flat ice ceiling have formed between 1997 and today. Several hypotheses could be advanced to explain its formation.

Firstly the origin of ice could be attributed to the freezing of stagnant water. A cycle of water filling - formation of "lake-ice" - draining when an opening is drilled in the ice mass has been reported by Turri et al. (2003) in the Moncodena ice cave (Lombardy). In their case, the freezing starts at the air-water interface and spreads down until no more unfrozen water is available. A similar event could have occurred in the Diablotins ice cave, when a part of the stagnant water found in the lower gallery between 1996 and 2005 had frozen in contact with the overcooled cave walls. This could explain the flat morphology of the ice-ceiling in the "chimney-room" and the occurrence of very transparent ice with some bubbles in the lateral ice on the "intermediate corridor" (Ford and Williams, 1989).

The second hypothesis is linked to the condensation processes. Lauriol and Clark (1993) reported the occurrence of ice ceilings in the subhorizontal gallery of Grande Caverne Glacée (northern Yukon) and attributed their origin as an accumulation of hexagonal ice (hoarfrost) growing down from the roof of the cave. Lauriol and Clark (1993) also explained that the initial hoarfrost accumulation could have evolved by cycles of sublimation and refreezing of ice, changing the initial crystallographic structures. Thus the ice ceiling encountered in Grande Caverne Glacée presented an irregular crystal growth arrangement and a high porosity formed by both occluded and interconnected bubbles. Such crystal structures seem to be very similar to those observed in the ice ceiling of the Diablotins ice cave. This process could be also relatively rapid, since the ceiling ice accumulation in the Grand Caverne Glacée is about $1.5 \mathrm{~m}$ thick and quite young (50-70 years). In the Diablotins ice cave, the rate of ice formation by the freezing of air humidity from the airflow could also have been accelerated by the supply of humidity from the unfrozen water pocket.

Both theories could also be mixed to explain the rapid ice mass increase and the type of ice founded today in the Diablotins ice cave, which could have a mixed origin of freezing of infiltrating water and of condensation of saturated air inside the cave during outward ventilation phases. After the whole draining of the water pocket in the lower gallery (since 2006-2007), a strong airflow has afterwards carved the current morphologies of ice surface. Nevertheless ice drilling and more detailed ice analysis will be necessary in the future to validate or disprove these hypotheses.

\section{Conclusions and perspectives}

The main conclusion of our study is that an efficient air circulation process by chimney-effect currently determined both the cave climate and the seasonal ice mass evolution. Airflow direction inside the lower gallery seasonally reverses when the external air temperature crosses a thermal threshold of about $+2{ }^{\circ} \mathrm{C}$. During winter, drying and strong cooling occurred in the ice cave, directly linked to the evolution of atmospheric air temperature and relative humidity. The main loss of ice is recorded during winter by sublimation. Melting in summertime is a secondary effect. During the snowmelt period, congelation ice formed in the ice cave.

The a priori surprising increase of the ice mass since 1994, which plugged almost entirely the lower gallery in 1995 seems to be linked to a transition from dryer, milder and less snow covered winters between 1989 and 1993, to wetter, colder and snowy winters in 1994 and 1995. Due to the plugging of the narrow sections of the gallery by ice, a temporary water pocket has then occurred until 2005, explaining partially the origin and morphology of ice encountered in the Diablotins ice cave.

Nevertheless more detailed measurements are required in the near-future to analyse the internal structures of the ice and to quantify the rate of sublimation/condensation processes. Main challenges lie in the observation and quantification of changes in ice within hourly or daily time interval by the use of automatic cameras, ultrasonic range sensors and/or laser scanning. Finally, the current re-opening of the lower gallery will please the speleologists of the SCPF, who waited for 20 years to reach again the deepest parts of the Gouffre des Diablotins.

Acknowledgements. Special thanks are due to the Société Fribourgeoise des Sciences Naturelles and the Fonds de Recherche de l'Université de Fribourg for their financial support in the Diablotins ice cave project. We also thank all the members of the Spéléo-Club des Préalpes Fribourgeoises for their valuable cooperation. Many thanks also to the two anonymous reviewers for their useful comments, and to Walter Leimgruber for editing the English text.

Edited by: F. Obleitner 


\section{References}

Arenson, L. U. and Sego, D. C.: Considering convective air fluxes in the design of engineered structures in cold regions, Sea to Sky Geotechnique, 1033-1040, 2006.

Atkinson, T. C., Smart, P. L., and Wigley, T. M. L.: Climate and natural radon levels in Castleguard cave, Columbia icefields, Alberta, Canada, Arctic Alpine Res., 15, 4, 487-502, 1983.

Bella, P.: Morphology of ice surface in the Dobsina ice cave, in: Proceedings of the 2nd International Workshop on Ice caves, Demanovska Dolina, Slovak Republic, 8-12 May 2006, 15-23, 2006.

Bovey, M.: Gouffre des Diablotins, in Akten des 10. Nationalen Kongresses für Höhlenforschung, Breitenbach, Switzerland, 170-172, 1995.

Delaloye, R., Reynard, E., Lambiel, C., Marescot, L., and Monnet, R.: Thermal anomaly in a cold scree slope (Creux-du-Van, Switzerland), in: Proceedings of the 8th International Conference on Permafrost, Zürich, Switzerland, 21-25 July 2003, 175180, 2003.

Forbes, J.: Air temperature and relative humidity study: Torgac cave, New Mexico, J. Cave Karst Stud., 60(1), 27-32, 1998.

Ford, D. C. and Williams, P. W.: Karst geomorphology and hydrology, Chapman and Hall, London, 1989.

Jutzet, J. M.: Brèves nouvelles: Gouffre B15 aux Morteys (Préalpes fribourgeoises), Stalactite, Société Suisse de Spéléologie, 41(2), 99, 1991.

Lauriol, B., Carrier, L., and Thibaudeau, P.: Topoclimatic zones and ice dynamics in the caves of the northern Yukon, Canada, Arctic, 41(3), 215-220, 1988.

Lauriol, B. and Clark, I. D.: An approach to determine the origin and age of massive ice blockages in two arctic caves, Permafrost Periglac., 4, 77-85, 1993.

Lauriol, B., Prévost, C., and Lacelle, D.: The distribution of diatoma flora in ice caves of the northern Yukon Territory, Canada: relationship to air circulation and freezing, Int. J. Speleol., 35(2), 83-92, 2006.

Law, J. and vanDijk, D.: Sublimation as a geomorphic process: a review, Permafrost Periglac., 5, 237-249, 1994.

Lismonde, B.: Mesure de la propagation d'une perturbation de pression au Trou qui Souffle (Méaudre, Isère), Karstologia, 22(2), 4347, 1993.

Lismonde, B.: L'âne de Buridan, le principe de Curie et l'effet de cheminée: courants d'air dans les cavités en forme de U, Karstologia, 37(1), 23-28, 2001.

Lismonde, B.: Climatologie du monde souterrain: Vents des ténèbres, Edition du Comité Départemental de Spéléologie de Isère, Tome 1, 2002a.
Lismonde, B.: Climatologie du monde souterrain: Aérologie des systèmes karstiques, Edition du Comité Départemental de Spéléologie de Isère, Tome 2, $2002 \mathrm{~b}$.

Luetscher, M.: Variations spatio-temporelles du volume de glace à la Glacière de Monlési (Boveresse/NE), Cavernes, 2, 3-7, 2004.

Luetscher, M. and Jeannin, P. Y.: Temperature distribution in karst systems: the role of air and water fluxes, Terra Nova, 16, 344350, doi:10.1111/j.1365-3121.2004.00572, 2004a.

Luetscher, M. and Jeannin, P. Y.: A process-based classification of alpine ice caves, Theoretical and Applied Karstology, 17, 5-10, 2004 b.

Luetscher, M.: Processes in ice caves and their significance for paleoenvironmental reconstructions, Ph.D. thesis, Swiss Institute for Speleology and Karst Studies (SISKA), 51 pp., 2005.

Luetscher, M., Jeannin P. Y., and Haeberli, W.: Ice caves as an indicator of winter climate evolution: a case study from the Jura Mountains, Holocene, 15(7), 982-993, 2005.

Luetscher, M., Lismonde, B., and Jeannin, P. Y.: Heat exchanges in the heterothermic zone of a karst system: Monlesi cave, Swiss Jura Mountains, J. Geophys. Res., 113, F02025, doi:10.1029/2007JF000892, 2008.

Morard, S., Delaloye, R., and Dorthe, J.: Seasonal thermal regime of a mid-latitude ventilated debris accumulation, in: Proceedings of the 9th International Conference on Permafrost, Fairbanks, Alaska, 29 June-3 July 2008, 1233-1238, 2008.

Ohata, T., Furukawa, T., and Higuchi, K.: Glacioclimatological study of perennial ice in the Fuji ice cave, Japan. Part 1. Seasonal variation and mechanism of maintenance, Arctic Alpine Res., 26(3), 227-237, 1994a.

Ohata, T., Furukawa, T., and Osada, K.: Glacioclimatological study of perennial ice in the Fuji ice cave, Japan. Part 2. Interannual variation and relation to climate, Arctic Alpine Res., 26(3), 238244, 1994b.

Rachlewicz, G. and Szczucinski, W.: Seasonal, annual and decadal ice mass balance changes in the ice cave Jaskinia Lodowa w Ciemniaku, the Tatra Mountains, Poland, Theoretical and Applied Karstology, 17, 11-18, 2004.

Saar, R.: Die Dachstein-Rieseneishöhle nächst Obertraun und ihre Funktion als dynamische Wetterhöhle, Jb d. oö Musealsvereins, Linz, 263-319, 1955.

SCPF: Spéléo-Club des Préalpes Fribourgeoises, http://www.scpf. info/, 2010.

Turri, S., Citterio, M., Bini, A., Maggi, V., Udisti, R., Stenni, B.: Etude glaciologique et climatologique des cavités glacées du Moncodeno (Grigna septentrionale, province de Lecco, Lombardie), Karstologia, 42(2), 37-44, 2003. 